\title{
A Feasible Technique in Laparoscopic Excision for Juvenile Cystic Adenomyosis: A Case Report, Literature Review, and Surgical Video
}

\author{
Masafumi Katakura, Yukiko Katagiri, Kuniaki Ota *D, Takafumi Mukai, Kentaro Nakaoka, Toshimitsu Maemura \\ and Mineto Morita
}

check for updates

Citation: Katakura, M.; Katagiri, Y.; Ota, K.; Mukai, T.; Nakaoka, K.;

Maemura, T.; Morita, M. A Feasible Technique in Laparoscopic Excision for Juvenile Cystic Adenomyosis: A Case Report, Literature Review, and Surgical Video. Endocrines 2021, 2, 284-292. https://doi.org/10.3390/ endocrines 2030026

Academic Editors: Osamu Hiraike and Akira Iwase

Received: 31 May 2021

Accepted: 3 August 2021

Published: 23 August 2021

Publisher's Note: MDPI stays neutral with regard to jurisdictional claims in published maps and institutional affiliations.

Copyright: (c) 2021 by the authors. Licensee MDPI, Basel, Switzerland. This article is an open access article distributed under the terms and conditions of the Creative Commons Attribution (CC BY) license (https:/ / creativecommons.org/licenses/by/ $4.0 /)$.
Obstetrics and Gynecology, School of Medicine, Toho University, Tokyo 143-8541, Japan; masafumi.katakura@med.toho-u.ac.jp (M.K.); yukikonk@med.toho-u.ac.jp (Y.K.); takafumi.mukai@med.toho-u.ac.jp (T.M.); kentarou.nakaoka@med.toho-u.ac.jp (K.N.); maemura@med.toho-u.ac.jp (T.M.); mmorita@med.toho-u.ac.jp (M.M.)

* Correspondence: kuniakiota@gmail.com; Tel.: +81-3-3762-4151
Abstract: Background: Juvenile cystic adenomyosis (JCA) is a rare uterine lesion. We present the case of a young woman who was diagnosed with JCA and subsequently managed with laparoscopic cyst removal with sharp and blunt dissection. Moreover, we provide a literature review and a surgical video. Case: A 22-year-old nulliparous woman presented with severe dysmenorrhea and was assessed using contrast-enhanced abdominal computed tomography, transvaginal ultrasonography and pelvic magnetic resonance imaging, and diagnosed with a cystic lesion on the left side of the myometrium. She underwent laparoscopic cyst excision and uterine reconstruction. Histology was suggestive of JCA. The dysmenorrhea resolved postoperatively. Conclusion: Surgical resection is the first choice of treatment for cystic adenomyosis, and a laparoscopic approach using scissor forceps is effective.

Keywords: juvenile cystic adenomyosis; laparoscopic adenomyomectomy; scissors forceps

\section{Introduction}

Cystic adenomyosis is a type of uterine cystic lesion that accounts for $0.35 \%$ of uterine tumors [1]. Cystic adenomyosis is classified into adult and juvenile types according to the age of onset. Both types often cause severe menstrual pain, and the juvenile type is thought to be due to abnormal development of the Müllerian ducts. Takeuchi et al. presented nine cases and developed the following diagnostic criteria for "juvenile cystic adenomyoma (JCA)": age less than 30 years, cystic lesion of 1-cm diameter or more independent of the uterine lumen and covered by an enlarged myometrium on diagnostic imaging, and severe dysmenorrhea [2]. Drug therapy may be effective, but only temporarily, and surgical treatment is required for a definite improvement in pain $[3,4]$. Considering the size of the lesion, laparoscopic surgery is the first choice if it is technically feasible [5,6]. However, unlike myoma, adenomyosis does not have a well-defined border; hence, complete enucleation may be difficult even with cystic adenomyosis [7]. Furthermore, surgical treatment of juvenile cystic adenomyosis should be considered for subsequent pregnancies because uterine rupture after adenomyomectomy is common and potentially lethal [8]. Recently, some reports have described that laparoscopic lesion resection has a significant effect on cystic adenomyosis, although few reports have described specific resection techniques [9,10]. We report a case of histopathologically confirmed juvenile cystic adenomyosis with severe primary dysmenorrhea and isolated cystic myometrial lesions on pelvic imaging, which were completely resolved following treatment with a feasible technique by laparoscopic surgery. Consent from a patient and her parents was obtained for this study. This study was reported according to the Surgical Case Report (SCARE) criteria [11]. 


\section{Case Presentation}

A 22-year-old nulliparous woman had a history of severe and worsening dysmenorrhea with cramps since the preceding 8 months, which was insufficiently relieved by a combination of non-steroidal anti-inflammatory drugs and oral contraceptive pills. She had severe dysmenorrhea and complained of non-cyclical chronic pelvic pain since she went through menarche when she was 13 years old. She visited our hospital and underwent an ultrasound examination, which revealed a $30-\mathrm{mm}$ pelvic mass on the right side of the uterus, with dense echoes, and an extremely rich blood signal in the cyst wall (Figure 1). Subsequently, contrast-enhanced abdominal computed tomography (CT) revealed a cystic lesion measuring $3 \mathrm{~cm}$ in diameter, on the left wall of the uterine corpus (Figure 2). On pelvic magnetic resonance imaging (MRI), the T1-weighted image revealed a hyperintense cyst on the left side of the uterus, and the T2-weighted image showed a normal uterine cavity and a hypointense lesion on the left side of the myometrium. The cyst did not exhibit diffusion restriction in diffusion-weighted images or the Apparent Diffusion Coefficient Map (Figure 3). No urogenital anomalies were noted on CT or MRI. The bilateral adnexa appeared normal. We advised laparoscopic surgery with possible resection of the cystic mass to relieve persistent pelvic pain. The patient provided informed consent prior to the procedure and was admitted to the hospital the day before the procedure. The bowel was prepared using a sodium phosphate solution enema. Antibiotic prophylaxis was administered at the time of anesthesia induction. Laparoscopic surgery was performed under general anesthesia. Carbon dioxide pneumoperitoneum with a pressure of $10 \mathrm{mmHg}$ was created using a Veress needle at the umbilicus. Peritoneal entry was achieved by direct trocar insertion at the umbilicus. Three accessory port techniques were used: two in the suprapubic area and one in the lower quadrant lateral to the right inferior epigastric artery. Laparoscopy revealed a 3-cm uterine mass arising from the left lateral uterine wall extending towards the left broad ligament. Before cyst removal, diluted epinephrine $(1: 1,000,000)$ was injected into the posterior wall of the uterus using 23-gauge suction needles (Hakko Medical, Nagano, Japan). The serosa was incised using an ultrasonic scalpel (Harmonic Scalpel; Ethicon Endo-Surgery, Cincinnati, OH, USA). After incising the posterior uterine wall, adenomyotic foci were identified, and only the adenomyotic cysts were enucleated with tactile confirmation of the boundaries between the adenomyotic tissue and normal muscle layer using scissor forceps. The cyst was gently removed without rupturing. The cyst was placed in Morsafe ${ }^{\mathrm{TM}}$ (Balmer Médical, SA, Switzerland) and morcellated using a Rotocut G1 morcellator (Karl Storz GmbH \& Co. KG, Tuttlingen, Germany). Inside the cyst, chocolate-colored fluid was visible. The myometrial defect was closed in two layers using 0 PDS II sutures (Ethicon Japan, Tokyo, Japan). Finally, the operated uterus was wrapped with oxidized regenerated cellulose (Interceed; Ethicon, Japan, Tokyo, Japan) to prevent adhesion to adjacent tissues, after washing the pelvic cavity with copious amounts of saline. The surgery was completed in $69 \mathrm{~min}$ with minimal blood loss. The specimen weighed $14 \mathrm{~g}$ (Figure 4). The detailed procedure of the laparoscopic surgery is presented in the video (Supplementary Materials). Postoperative pathology revealed myometrial cysts and bleeding on the inner wall. Microscopic examination confirmed the presence of endometriotic cysts (Figure 5). Based on the histopathology results and laparoscopy findings, cystic adenomyosis was diagnosed postoperatively. The patient was discharged 4 days after the surgery. One month after the surgery, postoperative transvaginal ultrasonography revealed complete resolution of the myometrial cystic lesion and restoration of the normal anatomy. She no longer experienced dysmenorrhea. Preoperatively, the severity of dysmenorrhea was 97 on a visual analog scale ranging from 0 (no pain) to 100 (extremely severe pain), whereas the postoperative score was 2. 

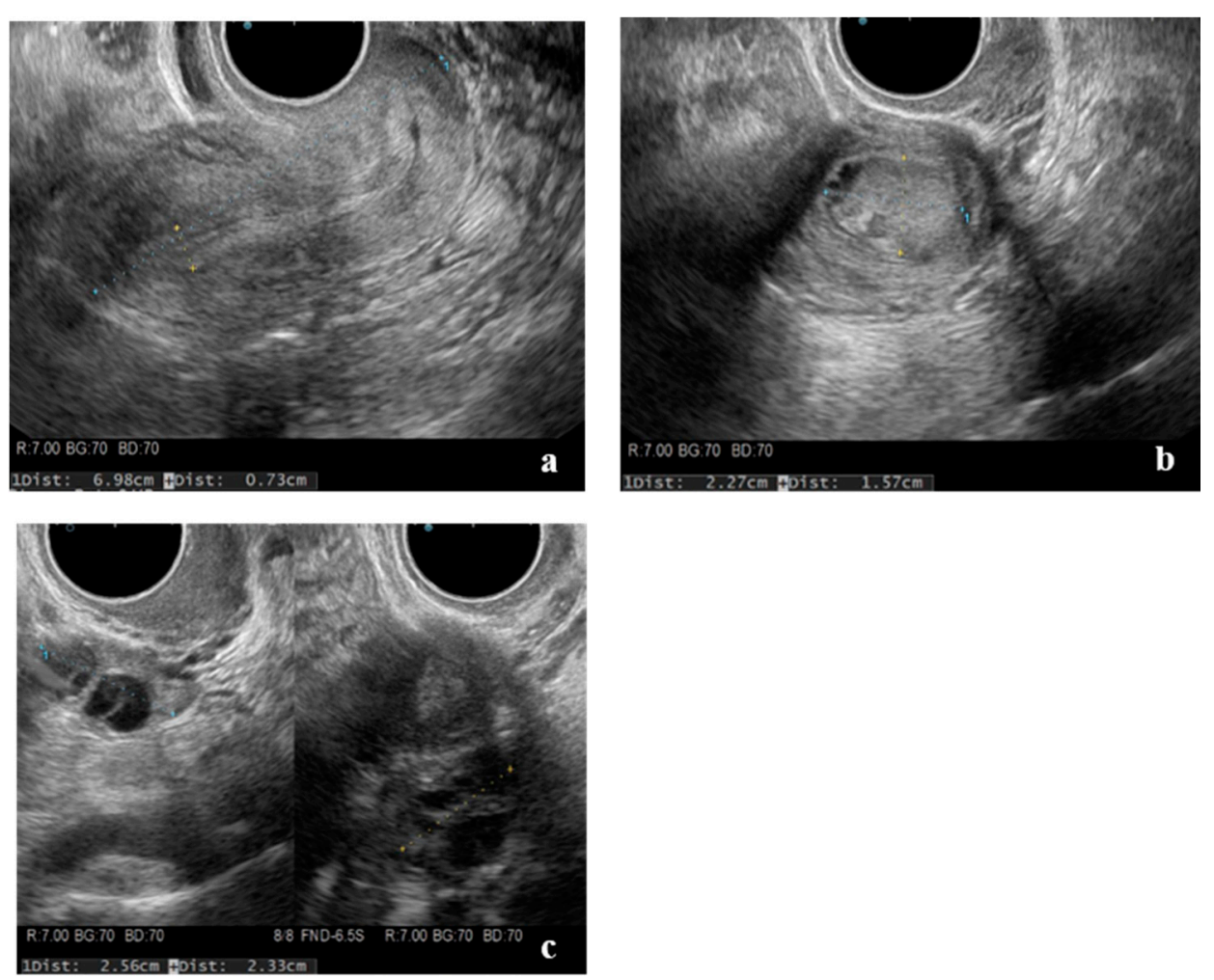

Figure 1. Transvaginal ultrasonography. (a) Sagittal section of the uterus, (b) hypoechoic lesion in the left lateral myometrium, and (c) no bilateral ovarian swelling.

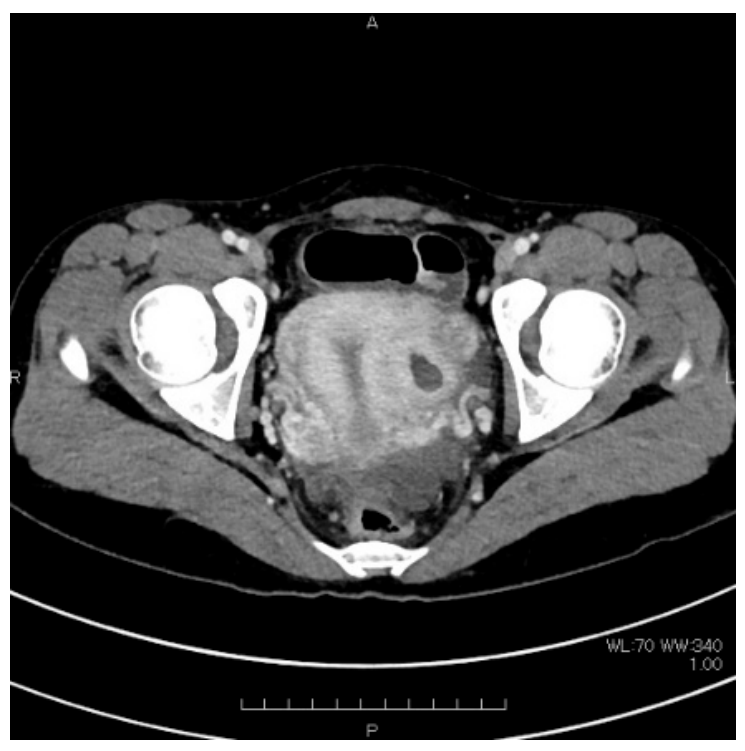

Figure 2. Pelvic contrast-enhanced computed tomography. Cystic shadow of $3 \mathrm{~cm}$ in diameter on the left wall of the uterus. 

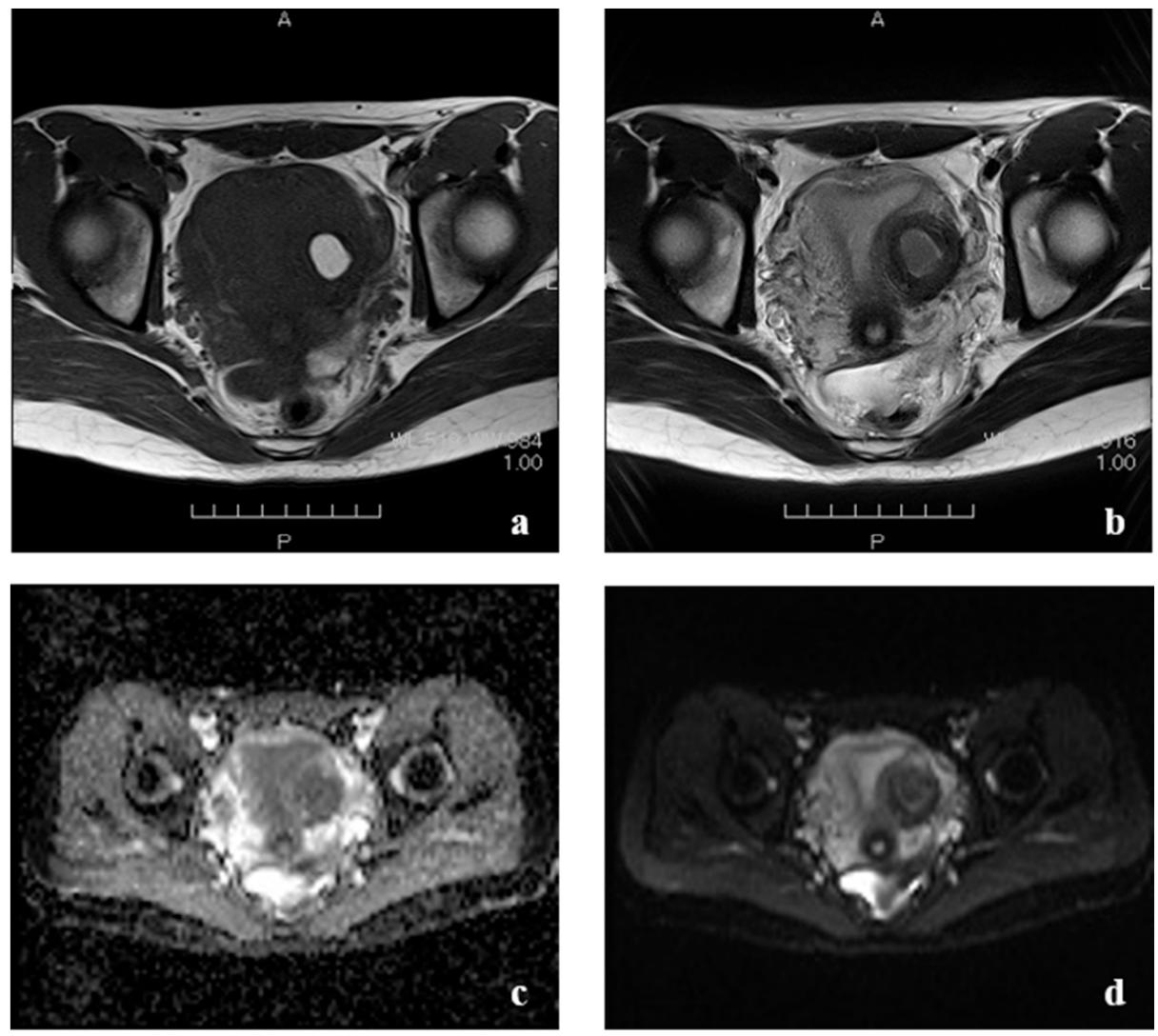

Figure 3. Pelvic magnetic resonance imaging. (a) T1-weighted image showing a hyperintense cyst in the left side of the uterus. (b) T2-weighted image showing a normal uterine cavity and a hypointense lesion in the left side of the myometrium. (c) The cyst did not show any diffusion restriction on diffusion-weighted images. (d) Apparent Diffusion Coefficient Map.
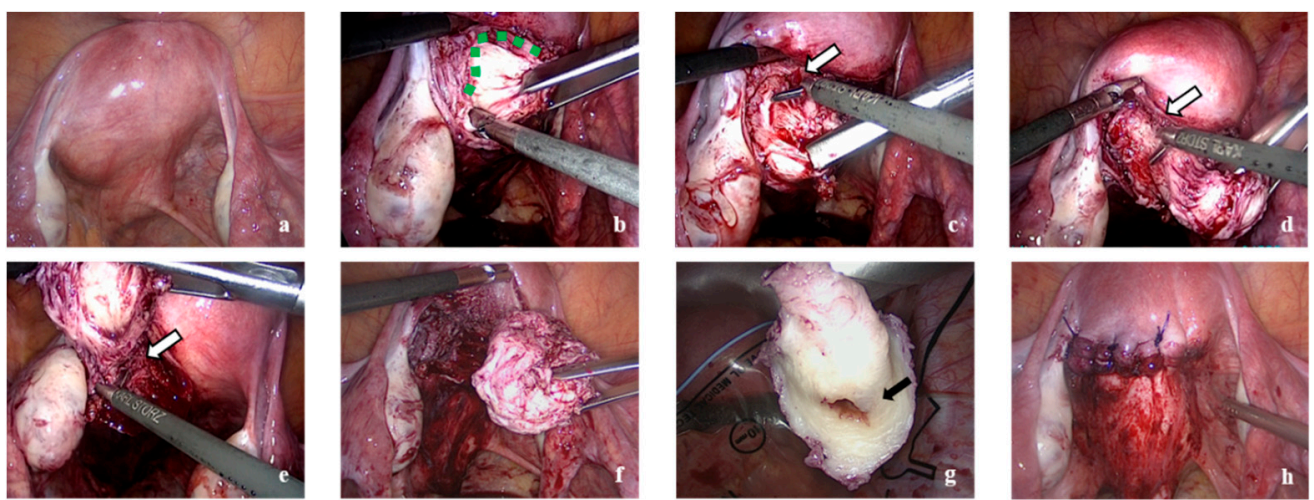

Figure 4. (a) A bulge is seen over the left side, posterior uterine myometrium. (b) The boundary of adenomyotic tissue and normal myometrium (green dotted line). (c-e) Resection for fibrotic tissue as the border between adenomyotic tissue and normal myometrium with the scissor forceps (white arrow). (f) The cyst could gently be removed without rupture. (g) Black arrow indicating the cystic capsule with the chocolate fluid. (h) Wound was repaired after cystectomy. 


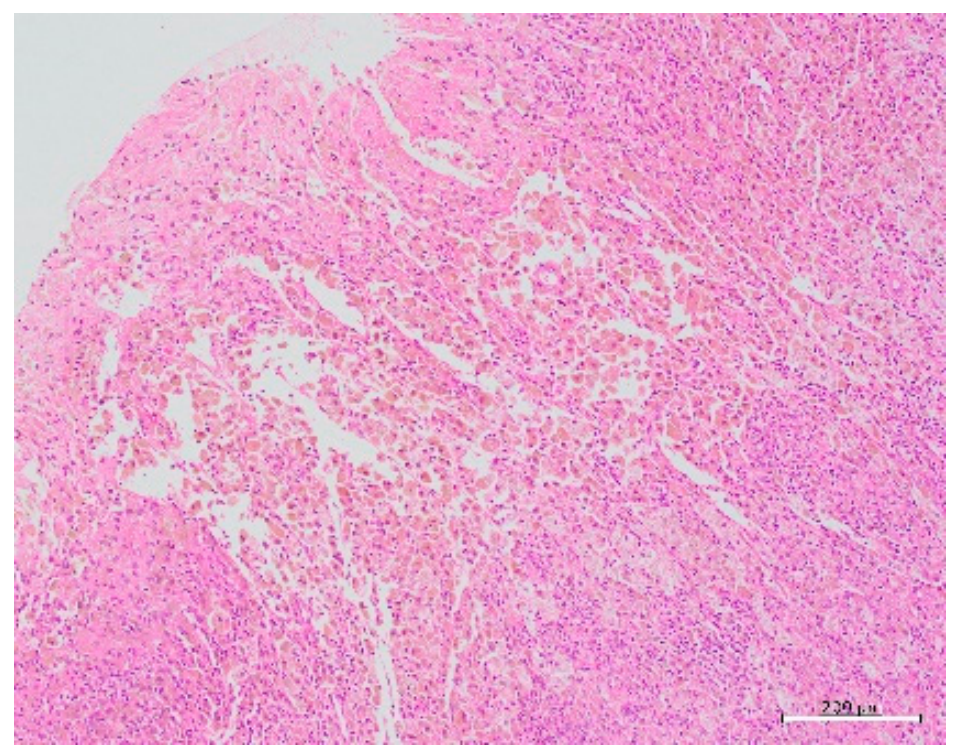

Figure 5. Histopathological picture showing glandular tissue with round nuclei and interstitial tissue scattered in islands within the tissue.

\section{Discussion}

Cystic adenomyosis is rare and usually associated with diffuse adenomyosis. Histologically, it is associated with diffuse uterine adenomyosis, which has a thick, viscous fluid that is chocolate or tar-colored and contains varying amounts of endometrial stroma below the glandular epithelium [12]. Moreover, cystic adenomyosis is classified into adult and juvenile types based on the age of onset [6]. Additionally, the two groups differ in terms of their clinical features and are believed to have different origins. Since the first menstruation, clinical symptoms are mainly severe dysmenorrhea and chronic abdominal cramps that are resistant to drug therapy [13]. The present case was histologically diagnosed as cystic adenomyosis, classified as the juvenile type based on the age of onset, with clinical features of severe dysmenorrhea, and a refractory nature towards drugs, beginning from the first menstruation. Previous reports have recommended resection of cystic adenomyoma to reduce or eliminate dysmenorrhea, although there are few reports of improvement observed with drug therapy $[14,15]$. The adult type of the disease is common among women who do not have issues with infertility, and total hysterectomy is often the treatment of choice, improving the quality of life. However, the juvenile type occurs at a young age and fertility preservation is desired in several cases. Therefore, adenomyomectomy is the treatment of choice in most cases [9]. However, the precise method of adenomyomectomy is not established, as the boundary between the lesion of adenomyosis and normal myometrium is unclear. In fact, the majority of methods for the treatment of adenomyomectomy have a high recurrence rate, either because the resection of the lesion may be insufficient or excess of the normal myometrium may be removed $[16,17]$. Several reports suggest that manual dissection by laparotomy is more reliable, as it permits the easy tactile identification of the lesion boundary [18]. Although the boundary of cystic adenomyosis between adenomyosis and normal myometrium is relatively clear on imaging, it is difficult to resect completely. Nabeshima et al. attempted laparotomy for cystic adenomyomectomy but failed to achieve complete resection [19]. Conversely, since the introduction of the power instrument in the 1980s, laparoscopic surgery has become more widespread and has become a necessary tool for incision and tissue collection, while shortening the operation time. However, laparoscopic adenomyomectomy is especially discussed in terms of its surgical adequacy, since a power instrument such as a harmonic scalpel causes hardening and discoloration of the incision surface due to thermal degeneration, and the boundary between the adenomyosis and normal myometrium becomes increasingly unclear and technically more difficult, although the number of reports on laparoscopic adenomyomectomy has increased. We 
recently proposed the use of cold scalpels instead of a power instrument, such as harmonic scalpels, because the electrosurgery-induced thermal denaturation causes difficulty in distinguishing the boundary between adenomyosis and normal endometrium [20]. In this case, laparoscopic removal was possible, and the symptoms resolved completely. The technique of removing the cyst with scissors forceps while identifying the cyst and the normal myometrium layer made it possible to remove the cyst with no residual lesion. Regarding the effectiveness of dissection, laparoscopic surgery is not inferior to laparotomy and can be expected to successfully complete the operation.

To our knowledge, 22 reports of surgical treatment for juvenile cystic adenomyosis have been described (Table 1), almost all of which were preoperatively treated with NSAIDs or OC, as patients refractory to medications may be considered for surgical management. The operation has been performed laparoscopically in recent years; however, power instruments such as the ultrasonic scalpel or monopolar needle techniques have been used for cyst excision, and there have been no reports of sharp and blunt removal without employing the power instruments typically used for complete tumor removal, except in the present case. To suture the myometrial defect, almost all cases described multiple layer closure with absorbable sutures. Our report revealed no significant difference in operative time or blood loss compared to the methods used in previous reports, suggesting that this method is used to complete the surgery without problems. Based on previous reports, no difference was noted in the location of the cyst between the left and right sides, or between the anterior and posterior sides, suggesting that cysts can develop in the myometrium of any region. Cystic adenomyosis is considered a congenital abnormality caused by abnormal development of the Müllerian ducts [6]; however, there have been no cases of Mullerian duct malformation, such as traffic with cysts, uterine malformation, or abnormal fallopian tube formation, as noted on MRI, sonohysterography, or drip infusion pyelography. The cyst size was approximately $30 \mathrm{~mm}$ in previous reports and in this report. CA125 was mildly elevated with a median of $38 \mathrm{U} / \mathrm{mL}$ in previous reports and $51.9 \mathrm{U} / \mathrm{mL}$ in this report. Pelvic pain and dysmenorrhea almost completely resolved after surgery. The median visual analogue scale scores from previous reports was 6 , and the median was 2 in our report. Thus, although the literature review shows that the characteristics of our patient were not majorly different from those of patients from previous reports, this case is a valuable report of a new technique that is different from that of previous reports. 
Table 1. 22 reports of surgical treatment for juvenile cystic adenomyosis.

\begin{tabular}{|c|c|c|c|c|c|c|c|c|c|c|c|c|c|c|c|c|c|c|}
\hline Case & $\begin{array}{l}\text { Age, } \\
\text { Years }\end{array}$ & G & $\mathrm{P}$ & $\begin{array}{l}\text { Menarche, } \\
\text { Years }\end{array}$ & $\begin{array}{c}\text { Cyst } \\
\text { Size, mm }\end{array}$ & $\begin{array}{c}\text { Cyst } \\
\text { Location }\end{array}$ & $\begin{array}{l}\mathrm{CA} 125, \\
\mathrm{U} / \mathrm{mL}\end{array}$ & $\begin{array}{c}\text { Previous Medical } \\
\text { Management }\end{array}$ & $\begin{array}{l}\text { Mullerian } \\
\text { Anomalies }\end{array}$ & Surgery & Intraoperative Findings & Device & Suture & $\begin{array}{l}\text { Specimen } \\
\text { Weight, } \\
\mathrm{g}\end{array}$ & $\begin{array}{c}\text { Ope } \\
\text { Duration, } \\
\text { min }\end{array}$ & $\begin{array}{l}\text { Bood } \\
\text { Loss, } \\
\text { mL }\end{array}$ & $\begin{array}{l}\text { Postope } \\
\text { VAS } \\
(0-100)\end{array}$ & Reference \\
\hline 1 & 16 & 0 & 0 & 12 & 30 & Left & $\mathrm{N} / \mathrm{A}$ & None & DIP: normal & Open & $3 \mathrm{~cm}$, left & $\mathrm{N} / \mathrm{A}$ & $\mathrm{N} / \mathrm{A}$ & $\mathrm{N} / \mathrm{A}$ & $\mathrm{N} / \mathrm{A}$ & $\mathrm{N} / \mathrm{A}$ & $\mathrm{N} / \mathrm{A}$ & Tamura, 1996 [15] \\
\hline 2 & 27 & 0 & 0 & $\mathrm{~N} / \mathrm{A}$ & 20 & Right & $\mathrm{N} / \mathrm{A}$ & $\begin{array}{l}\text { NSAIDs, GnRH } \\
\text { agonist, OC }\end{array}$ & $\mathrm{N} / \mathrm{A}$ & Laparoscopy & $2 \mathrm{~cm}$, right & $\begin{array}{c}\text { Harmonic scalpel, a } \\
\text { special tension device }\end{array}$ & $\begin{array}{c}\text { myometrium: } 1 \text { polyglactin } Z \\
\text { suture, serosal: continuous } 4-0 \\
\text { polypropylene suture }\end{array}$ & N/A & 190 & few & 0 & Nabeshima, $2007[19$ \\
\hline 3 & 19 & 0 & 0 & $\mathrm{~N} / \mathrm{A}$ & 30 & Right & 40.9 & GnRH agonist & HSG: normal & Laparoscopy & posterior, right & $\begin{array}{c}\text { Harmonic scalpel, a } \\
\text { special tension device }\end{array}$ & $\begin{array}{l}\text { myometrium: } 0 \text { polyglactin } \\
\text { suture, serosala continuous } 4-0 \\
\text { polypropylene suture } 4\end{array}$ & & 234 & $<100$ & 0 & Nabeshima, $2003[3]$ \\
\hline 4 & 23 & 0 & 0 & 12 & 30 & Left & 2.5 & $\begin{array}{l}\text { Danazol, GnRH } \\
\text { agonist OC }\end{array}$ & HSG: normal & Open & $3 \mathrm{~cm}$, anterior, left & N/A & $\mathrm{N} / \mathrm{A}$ & N/A & 80 & 86 & 0 & Kamio, 2007 [4] \\
\hline 5 & 16 & 0 & 0 & $\mathrm{~N} / \mathrm{A}$ & $\mathrm{N} / \mathrm{A}$ & Right & $\mathrm{N} / \mathrm{A}$ & $\begin{array}{l}\text { agonist, OC } \\
\text { None }\end{array}$ & HSG: normal & $\mathrm{N} / \mathrm{A}$ & right & N/A & $\mathrm{N} / \mathrm{A}$ & N/A & N/A & $\mathrm{N} / \mathrm{A}$ & $\mathrm{N} / \mathrm{A}$ & Ho, 2008 [21] \\
\hline 6 & 15 & 0 & 0 & $\mathrm{~N} / \mathrm{A}$ & 40 & Left & $\mathrm{N} / \mathrm{A}$ & $\mathrm{NSAIDS}_{\mathrm{O}} \mathrm{OC}$ & HSG: normal & Open & $\begin{array}{l}3 \mathrm{~cm} \text {, anterior, left, near the } \\
\text { round liament }\end{array}$ & $\mathrm{N} / \mathrm{A}$ & $\mathrm{N} / \mathrm{A}$ & N/A & $\mathrm{N} / \mathrm{A}$ & $\mathrm{N} / \mathrm{A}$ & $\mathrm{N} / \mathrm{A}$ & Potter, 1998 [22] \\
\hline 7 & 13 & 0 & 0 & $\mathrm{~N} / \mathrm{A}$ & 21 & Left & $\mathrm{N} / \mathrm{A}$ & $\mathrm{OC}$ & N/A & Not attempted & & & - & - & . & & & Fisseha, 2006 [23] \\
\hline 9 & 20 & 0 & 0 & 14 & 26 & Left & 40.5 & NSAIDs & HSG, DIP: normal & Laparoscopy & the uterine surface appeared & Harmonic scalpel & single-layer closure & N/A & 67 & $<50$ & 0 & Takeda, 2007 [6] \\
\hline 10 & 30 & 0 & 0 & $\mathrm{~N} / \mathrm{A}$ & 35 & & 43 & None & $\begin{array}{l}\text { HSG, DIP: normal } \\
\text { HSG DPP noman }\end{array}$ & Laparoscopy & $\begin{array}{l}\text { unchanged } \\
\text { N/A }\end{array}$ & $\mathrm{N} / \mathrm{A}$ & N/A & 10 & 70 & 20 & 20 & Takeuchi, 2010 [2] \\
\hline $\begin{array}{l}11 \\
12\end{array}$ & ${ }_{27}^{29}$ & $\begin{array}{l}0 \\
2\end{array}$ & $\begin{array}{l}0 \\
2\end{array}$ & $\begin{array}{l}\mathrm{N} / \mathrm{A} \\
\mathrm{N} / \mathrm{A}\end{array}$ & $\begin{array}{l}30 \\
42\end{array}$ & & $\begin{array}{l}141 \\
36\end{array}$ & $\begin{array}{l}\text { None } \\
\text { None }\end{array}$ & $\begin{array}{l}\text { HSG, IIP: normal } \\
\text { HSG, DIP: normal }\end{array}$ & $\begin{array}{l}\text { Laparascopy } \\
\text { Laparoscopy }\end{array}$ & $\begin{array}{l}\text { N/A } \\
\text { N/A }\end{array}$ & $\begin{array}{l}\text { N/A } \\
\text { N/A }\end{array}$ & $\begin{array}{l}\mathrm{N} / \mathrm{A} \\
\mathrm{N} / \mathrm{A}\end{array}$ & $\begin{array}{l}10 \\
10\end{array}$ & $\begin{array}{l}120 \\
70\end{array}$ & $\begin{array}{l}100 \\
50\end{array}$ & $\begin{array}{l}30 \\
20\end{array}$ & $\begin{array}{l}\text { Takeuchi, } 2010[2] \\
\text { Takeuchi, } 2010[2]\end{array}$ \\
\hline 13 & 20 & 0 & 0 & $\mathrm{~N} / \mathrm{A}$ & 28 & L. 3 & & OC & $\begin{array}{l}\text { HSG, DIP: normal } \\
\text { Hons }\end{array}$ & Laparoscopy & N/A & N/A & N/A & 11 & 96 & 52 & 20 & $\begin{array}{l}\text { Takeuchi, } 2010[2] \\
\text { Takent }\end{array}$ \\
\hline 14 & $\begin{array}{l}30 \\
28\end{array}$ & 2 & 2 & N/A & 30 & $\begin{array}{l}\text { L L } 3, \\
\text { R: } 6\end{array}$ & 34 & $\begin{array}{c}\text { None } \\
\text { GnRH aconist OC }\end{array}$ & $\begin{array}{l}\text { HSG, DIP: normal } \\
\text { HSG DIP normal }\end{array}$ & $\begin{array}{l}\text { Laparoscopy } \\
\text { apropcoy }\end{array}$ & N/A & N/A & N/A & 7 & 76 & 5 & 10 & 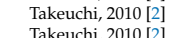 \\
\hline $\begin{array}{l}15 \\
16\end{array}$ & $\begin{array}{l}28 \\
23\end{array}$ & $\begin{array}{l}0 \\
0 \\
0\end{array}$ & ${ }_{0}^{0}$ & $\begin{array}{l}\text { N/A } \\
\text { N/A }\end{array}$ & $\begin{array}{l}25 \\
28 \\
28\end{array}$ & & $\begin{array}{l}12 \\
157\end{array}$ & $\begin{array}{l}\text { GnRH agonist, OC } \\
\text { OC }\end{array}$ & $\begin{array}{l}\text { HSG, DIP: normal } \\
\text { HSG DIP normal }\end{array}$ & $\begin{array}{l}\text { Laparoscopy } \\
\text { Laparoscopy }\end{array}$ & N/A & N/A & N/A & $\begin{array}{c}7 \\
35\end{array}$ & $\begin{array}{l}70 \\
75\end{array}$ & $\begin{array}{l}10 \\
50\end{array}$ & 2 & Takeuchi, 2010 [2] \\
\hline $\begin{array}{l}16 \\
17\end{array}$ & ${ }_{20}^{23}$ & 0 & $\begin{array}{l}0 \\
0\end{array}$ & $\begin{array}{l}\text { N/A } \\
\text { N/A }\end{array}$ & ${ }_{34}^{28}$ & & $\begin{array}{l}157 \\
34\end{array}$ & GnRH agonist & $\begin{array}{l}\text { HSG, , II: normal } \\
\text { HSG, DIP: normal }\end{array}$ & $\begin{array}{l}\text { Laparoscopy } \\
\text { Laparoscopy }\end{array}$ & $\begin{array}{l}\text { N/A } \\
\text { N/A }\end{array}$ & $\begin{array}{l}\text { N/A } \\
\text { N/A }\end{array}$ & $\begin{array}{l}N / A \\
N / A\end{array}$ & 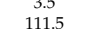 & 76 & $\begin{array}{l}50 \\
50\end{array}$ & ${ }_{20}^{30}$ & $\begin{array}{l}\text { lakeuchu, } 2010[2] \\
\text { Takeuchi } 2010[2]\end{array}$ \\
\hline 18 & 20 & 0 & 0 & N/A & ${ }_{34} 4$ & & $\begin{array}{l}34 \\
14\end{array}$ & GnRH agonist & HSG, DIP: normal & Laparoscopy & N/A & N/A & N/A & 4.1 & $\begin{array}{l}10 \\
49\end{array}$ & 10 & ${ }_{10}^{20}$ & Takeuchi, $2010[2]$ \\
\hline 19 & 16 & 0 & 0 & & 38 & Right & $\mathrm{N} / \mathrm{A}$ & NSAIDs, OC & HYS: normal & Laparoscopy & $4 \mathrm{~cm}$, posterior, right & $\begin{array}{l}\text { unipolar and bipolar } \\
\text { electrosurgery }\end{array}$ & 2-0 polyglactin & 20 & 50 & $\mathrm{~N} / \mathrm{A}$ & 0 & Kriplani, 2011 [5] \\
\hline 20 & 18 & 0 & 0 & $\mathrm{~N} / \mathrm{A}$ & 42 & Right & $\mathrm{N} / \mathrm{A}$ & NSAIDs, OC & HYS: normal & Laparoscopy & $5 \mathrm{~cm}$, right & $\begin{array}{l}\text { unipolar and bipolar } \\
\text { electrosurgery }\end{array}$ & 2-0 polyglactin & 25 & 80 & $\mathrm{~N} / \mathrm{A}$ & 10 & Kriplani, 2011 [5] \\
\hline 21 & 16 & 0 & 0 & N/A & 31 & $\mathrm{~N} / \mathrm{A}$ & $\mathrm{N} / \mathrm{A}$ & NSAIDs & HYS: normal & Laparoscopy & $5 \mathrm{~cm}$, anterior & unipolar and bipolar & 2-0 polyglactin & 18 & 60 & N/A & 0 & Kriplani, 2011 [5] \\
\hline 23 & 19 & 0 & 0 & $\mathrm{~N} / \mathrm{A}$ & 40 & Left & WNL & NSAIDs, OC & HSG: normal & Open & $\begin{array}{c}\text { broad ligament } \\
\text { anterior, left }\end{array}$ & $\begin{array}{l}\text { electrosurgery } \\
\text { scalpel }\end{array}$ & double layer closure & N/A & N/A & $\mathrm{N} / \mathrm{A}$ & 0 & Dogan, $2008[18]$ \\
\hline 24 & 19 & 0 & 0 & 13 & 20 & Left & & NSAIDs, OC & HYS: normal & Laparoscopy & $2 \mathrm{~cm}$, anterior, left & Harmonic scalpel & $\begin{array}{l}\text { 2/0 PDS myometrium, } \\
\text { 3/0 PDS serosa }\end{array}$ & N/A & 90 & $<20$ & 0 & Ball, 2009 [24] \\
\hline 25 & 15 & 0 & 0 & $\mathrm{~N} / \mathrm{A}$ & 47 & Right & $\mathrm{N} / \mathrm{A}$ & $\mathrm{OC}, \mathrm{GnRH}$ agonist & & $\begin{array}{l}\text { Robotic- } \\
\text { assisted } \\
\text { LLap }\end{array}$ & $4 \mathrm{~cm}$, anterior fundal, right & $\mathrm{N} / \mathrm{A}$ & four layers & $\mathrm{N} / \mathrm{A}$ & N/A & $\mathrm{N} / \mathrm{A}$ & $\mathrm{N} / \mathrm{A}$ & Akar, 2010 [25] \\
\hline 26 & 18 & 0 & 0 & 14 & 30 & Left & N/A & hormonal therapy & MRI: normal & Laparoscopy & $\begin{array}{l}3 \mathrm{~cm} \text {, lateral, left } \\
\end{array}$ & monopolar scissors & 2 layers, 2-0 vicryl & $\mathrm{N} / \mathrm{A}$ & 120 & few & Relieved & Ayra, 2021 [9] \\
\hline $\begin{array}{l}27 \\
28\end{array}$ & $\begin{array}{l}16 \\
17\end{array}$ & $\begin{array}{l}0 \\
0\end{array}$ & $\begin{array}{l}0 \\
0\end{array}$ & $\begin{array}{l}14 \\
13\end{array}$ & ${ }_{33}^{51}$ & $\begin{array}{l}\text { Right } \\
\text { Right }\end{array}$ & & $\begin{array}{c}\text { OC } \\
\text { NSAIDs, OC }\end{array}$ & $\begin{array}{l}\mathrm{N} / \mathrm{A} \\
\mathrm{N} / \mathrm{A}\end{array}$ & $\begin{array}{l}\text { Laparoscopy } \\
\text { Not attempted }\end{array}$ & $5 \mathrm{~cm}$, right, near the cornu & & & & & & & $\begin{array}{l}\text { Ayra, } 2021 \text { 19] } \\
\text { Branguinho, } 2012 \text { [13 }\end{array}$ \\
\hline 29 & 25 & 0 & 0 & 12 & 50 & N/A & 38 & $\begin{array}{l}\text { NSAIDS } \\
\text { NAS }\end{array}$ & N/A & $\begin{array}{l}\text { Laparoscopy } \\
\text { L }\end{array}$ & $\mathrm{N} / \mathrm{A}$ & monopolar hook & $\mathrm{N} / \mathrm{A}$ & $\mathrm{N} / \mathrm{A}$ & 70 & $<20$ & Relieved & $\begin{array}{l}\text { Cucinella, 2013 [10] } \\
\text { Cul }\end{array}$ \\
\hline 30 & 20 & 0 & & $\mathrm{~N} / \mathrm{A}$ & 30 & $\mathrm{~N} / \mathrm{A}$ & $\mathrm{N} / \mathrm{A}$ & N/A & $\mathrm{N} / \mathrm{A}$ & Laparoscopy & $\begin{array}{l}\mathrm{N} / \mathrm{A} \\
\text { bilocular crstof } 8 \mathrm{~cm}\end{array}$ & monopolar hook & barbed string & & & & Relieved & Kumakiri, 2013 [26] \\
\hline 31 & 27 & 0 & 0 & $\mathrm{~N} / \mathrm{A}$ & 75 & Right & 96 & OC & $\mathrm{N} / \mathrm{A}$ & Hysteroscopy & $\begin{array}{l}\text { bilocular cyst of } 8 \mathrm{~cm} \text {, } \\
\text { posterior }\end{array}$ & monopolar loop & None & $\mathrm{N} / \mathrm{A}$ & $\mathrm{N} / \mathrm{A}$ & $\mathrm{N} / \mathrm{A}$ & Relieved & Pontrelli, 2015 [27] \\
\hline $\begin{array}{l}32 \\
33\end{array}$ & $\begin{array}{l}23 \\
16\end{array}$ & 0 & $\begin{array}{l}0 \\
0\end{array}$ & 17 & $\begin{array}{l}39 \\
40\end{array}$ & $\begin{array}{c}\text { Right } \\
\text { Left }\end{array}$ & N/A & $\begin{array}{l}\text { None } \\
\text { None }\end{array}$ & $\begin{array}{l}\text { HYS: normal } \\
\text { HYS normal }\end{array}$ & $\begin{array}{l}\text { Open } \\
\text { Laparoscopy }\end{array}$ & $\begin{array}{l}\text { anterior, right side } \\
4 \mathrm{~cm} \text { left }\end{array}$ & N/A & $\begin{array}{l}\text { 1-0 vicryl } \\
1-0 \text { V-lock }\end{array}$ & $\begin{array}{l}\mathrm{N} / \mathrm{A} \\
\mathrm{N} / \mathrm{A}\end{array}$ & $\begin{array}{l}\mathrm{N} / \mathrm{A} \\
\mathrm{N} / \mathrm{A}\end{array}$ & N/A & Relieved & Dadhwal, 2017 [28] \\
\hline 34 & $\begin{array}{l}10 \\
19\end{array}$ & 0 & 0 & N/A & ${ }_{30}^{40}$ & Left & $\mathrm{N} / \mathrm{A}$ & $\begin{array}{l}\text { None } \\
\text { OC }\end{array}$ & $\begin{array}{l}\text { HYSS normal } \\
\text { N/A }\end{array}$ & $\begin{array}{l}\text { Laparososcopy } \\
\text { Not attempted }\end{array}$ & & & 1-0 V-lock & & & & & $\begin{array}{l}\text { Dahhwal, } 2017 \text { [ [28] } \\
\text { Petetrs, } 2018 \text { [299] }\end{array}$ \\
\hline 35 & 14 & 0 & 0 & $\mathrm{~N} / \mathrm{A}$ & 38 & Left & $\mathrm{N} / \mathrm{A}$ & progestins & MRI: normal & Laparoscopy & left side, near the cornu & monopolar needle & $\begin{array}{l}2 \text { layers using figure of } \\
8 \text { absorbable sutures }\end{array}$ & N/A & $\mathrm{N} / \mathrm{A}$ & $\mathrm{N} / \mathrm{A}$ & 40 & Protopapas, $2020[30$ \\
\hline 36 & 18 & 0 & 0 & 13 & 23 & Left & $\mathrm{N} / \mathrm{A}$ & OC, LNG-IUD & HYS: normal & Laparoscopy & $\begin{array}{l}\text { anterior, left, near the } \\
\text { round ligament }\end{array}$ & monopolar scissors & 2 layers, 0 - Vicryl, serosa: & $\mathrm{N} / \mathrm{A}$ & $\mathrm{N} / \mathrm{A}$ & $\mathrm{N} / \mathrm{A}$ & $\mathrm{N} / \mathrm{A}$ & Wilcox, 2020 [31] \\
\hline 37 & 18 & 0 & 0 & $\mathrm{~N} / \mathrm{A}$ & 36 & Left & $\mathrm{N} / \mathrm{A}$ & OC & HYS: normal & Laparoscopy & $\begin{array}{l}\text { round ligament } \\
\text { anterior, left, near the } \\
\text { round ligament }\end{array}$ & monopolar scissors & $\begin{array}{l}\text { myometrium: } 0 \text { Vicryl, serosa: } \\
\text { running stitch of } 2-0 \text { Vicryl }\end{array}$ & $\mathrm{N} / \mathrm{A}$ & $\mathrm{N} / \mathrm{A}$ & $\mathrm{N} / \mathrm{A}$ & $\mathrm{N} / \mathrm{A}$ & Wilcox, 2020 [31] \\
\hline Median & 19 & 0 & 0 & 13 & 30.5 & $\begin{array}{l}\text { R: } 18, \\
\text { L: } 16\end{array}$ & 38 & & & & & & & 10 & 75.5 & 50 & 6 & \\
\hline $\begin{array}{l}\text { This } \\
\text { case }\end{array}$ & 22 & 0 & 0 & 15 & 36 & $\mathrm{~L}$ & 51.9 & None & CT, MRI: None & Laparoscopy & $3 \mathrm{~cm}$, lateral, left side & $\begin{array}{l}\text { Harmonic Scalpel, } \\
\text { scissors forceps }\end{array}$ & 2 layers using 0 PDS & 14 & 69 & few & 2 & Present study \\
\hline
\end{tabular}

L: left, R: right, A: anterior, P: posterior, N/A: data not available, WNL: within normal limits, VAS: visual analogue scale, Hys: hysteroscopy, DIP: drip infusion pyelography. 


\section{Conclusions}

Cystic adenomyosis is mainly characterized by severe dysmenorrhea since the first menstruation and requires a fertility-sparing surgery for young women. Adenomyosis is difficult to completely resect, because the boundary between adenomyosis and normal myometrium is unclear. To our knowledge, we are the first to report a case of complete relief from severe dysmenorrhea by enucleation with laparoscopic adenomyomectomy using scissor forceps, which facilitates the easy tactile identification of the boundary, although previous reports have not described this in detail. Moreover, we need to consider the perinatal prognosis because of the risk of uterine rupture after incision of the myometrium; however, we believe that the surgical technique will provide new evidence.

Supplementary Materials: The following are available online at https:/ / www.mdpi.com/article / 10.3390/endocrines2030026/s1, Video S1: Enucleation of Cystic adenomyosis with laparoscopic adenomyomectomy using scissor forceps.

Author Contributions: Conceptualization, M.K. and K.O.; methodology, M.K. and T.M. (Takafumi Mukai); data collection, M.K. and K.N.; writing-original draft preparation, M.K. and K.O.; writing, review and editing, T.M. (Toshimitsu Maemura) and Y.K.; supervision, M.M. All authors have read and agreed to the published version of the manuscript.

Funding: Not applicable.

Institutional Review Board Statement: Not applicable.

Informed Consent Statement: Written informed consent was obtained from the patient for publication of this case report and accompanying images.

Acknowledgments: We would like to thank our patients for providing consent to share their cases and photos via this article.

Conflicts of Interest: The authors declare no conflict of interest.

\section{References}

1. Dubransky, V. Submuckose uterus cyste. Zbl. Gynak 1936, 60, 564.

2. Takeuchi, H.; Kitade, M.; Kikuchi, I.; Kumakiri, J.; Kuroda, K.; Jinushi, M. Diagnosis, laparoscopic management, and histopathologic findings of juvenile cystic adenomyoma: A review of nine cases. Fertil. Steril. 2010, 94, 862-868. [CrossRef] [PubMed]

3. Nabeshima, H.; Murakami, T.; Terada, Y.; Noda, T.; Yaegashi, N.; Okamura, K. Total Laparoscopic Surgery of Cystic Adenomyoma under Hydroultrasonographic Monitoring. J. Am. Assoc. Gynecol. Laparosc. 2003, 10, 195-199. [CrossRef]

4. Kamio, M.; Taguchi, S.; Oki, T.; Tsuji, T.; Iwamoto, I.; Yoshinaga, M.; Douchi, T. Isolated adenomyotic cyst associated with severe dysmenorrhea. J. Obstet. Gynaecol. Res. 2007, 33, 388-391. [CrossRef] [PubMed]

5. Kriplani, A.; Mahey, R.; Agarwal, N.; Bhatla, N.; Yadav, R.; Singh, M.K. Laparoscopic Management of Juvenile Cystic Adenomyoma: Four Cases. J. Minim. Invasive Gynecol. 2011, 18, 343-348. [CrossRef] [PubMed]

6. Takeda, A.; Sakai, K.; Mitsui, T.; Nakamura, H. Laparoscopic management of juvenile cystic adenomyoma of the uterus: Report of two cases and review of the literature. J. Minim. Invasive Gynecol. 2007, 14, 370-374. [CrossRef]

7. Nishida, M.; Takano, K.; Arai, Y.; Ozone, H.; Ichikawa, R. Conservative surgical management for diffuse uterine adenomyosis. Fertil. Steril. 2010, 94, 715-719. [CrossRef]

8. Osada, H. Uterine adenomyosis and adenomyoma: The surgical approach. Fertil. Steril. 2018, 109, 406-417. [CrossRef]

9. Arya, S.; Burks, H.R. Juvenile cystic adenomyoma, a rare diagnostic challenge: Case Reports and literature review. F S Rep. 2021, 2, 166-171. [CrossRef]

10. Cucinella, G.; Billone, V.; Pitruzzella, I.; Monte, A.I.L.; Palumbo, V.D.; Perino, A. Adenomyotic Cyst in a 25-Year-Old Woman: Case Report. J. Minim. Invasive Gynecol. 2013, 20, 894-898. [CrossRef]

11. Agha, R.A.; Borrelli, M.R.; Farwana, R.; Koshy, K.; Fowler, A.J.; Orgill, D.P.; Zhu, H.; Alsawadi, A.; Noureldin, A.; Rao, A.; et al. The SCARE 2018 statement: Updating consensus Surgical CAse REport (SCARE) guidelines. Int. J. Surg. 2018, 60, 132-136. [CrossRef] [PubMed]

12. Tahlan, A.; Nanda, A.; Mohan, H. Uterine adenomyoma: A clinicopathologic review of 26 cases and a review of the literature. Int. J. Gynecol. Pathol. 2006, 25, 361-365. [CrossRef]

13. Branquinho, M.M.; Marques, A.L.; Leite, H.B.; Silva, I.S. Juvenile cystic adenomyoma. BMJ Case Rep. 2012, 2012. [CrossRef] [PubMed]

14. Molitor, J.J. Adenomyosis: A clinical and pathologic appraisal. Am. J. Obstet. Gynecol. 1971, 110, 275-282. [CrossRef]

15. Tamura, M.; Fukaya, T.; Takaya, R.; Ip, C.W.; Yajima, A. Juvenile Adenomyotic Cyst of the Corpus Uteri with Dysmenorrhea. Tohoku J. Exp. Med. 1996, 178, 339-344. [CrossRef] [PubMed] 
16. Levgur, M. Therapeutic options for adenomyosis: A review. Arch. Gynecol. Obstet. 2007, 276, 1-15. [CrossRef]

17. Wada, S.-I.; Kudo, M.; Minakami, H. Spontaneous uterine rupture of a twin pregnancy after a laparoscopic adenomyomectomy: A case report. J. Minim. Invasive Gynecol. 2006, 13, 166-168. [CrossRef] [PubMed]

18. Dogan, E.; Gode, F.; Saatli, B.; Seçil, M. Juvenile cystic adenomyosis mimicking uterine malformation: A case report. Arch. Gynecol. Obstet. 2008, 278, 593-595. [CrossRef]

19. Nabeshima, H.; Murakami, T.; Nishimoto, M.; Sugawara, N.; Sato, N. Successful Total Laparoscopic Cystic Adenomyomectomy after Unsuccessful Open Surgery Using Transtrocar Ultrasonographic Guiding. J. Minim. Invasive Gynecol. 2008, 15, 227-230. [CrossRef]

20. Ota, Y.; Ota, K.; Takahashi, T.; Suzuki, S.; Sano, R.; Shiota, M. New surgical technique of laparoscopic resection of adenomyosis under real-time intraoperative ultrasound elastography guidance: A case report. Heliyon 2020, 6, e04628. [CrossRef]

21. Ho, M.-L.; Raptis, C.; Hulett, R.; McAlister, W.-H.; Moran, K.; Bhalla, S. Adenomyotic cyst of the uterus in an adolescent. Pediatric Radiol. 2008, 38, 1239-1242. [CrossRef]

22. Potter, D.-A.; Schenken, R.-S. Noncommunicating accessory uterine cavity. Fertil. Steril. 1998, 70, 1165-1166. [CrossRef]

23. Fisseha, S.; Smith, Y.-R.; Kumetz, L.-M.; Mueller, G.-C.; Hussain, H.; Quint, E.-H. Cystic myometrial lesion in the uterus of an adolescent girl. Fertil. Steril. 2006, 86, 716-718. [CrossRef] [PubMed]

24. Ball, E.; Ganji, M.; Janik, G.; Koh, C. Laparoscopic resection of cystic adenomyosis in a teenager with arcurate uterus. Gynecol. Surg. 2009, 6, 367-370. [CrossRef]

25. Akar, M.-E.; Leezer, K.-H.; Yalcinkaya, T.-M. Robot-assisted laparoscopic management of a case with juvenile cystic adenomyoma. Fertil. Steril. 2010, 94, 55-56. [CrossRef] [PubMed]

26. Kumakiri, J.; Kikuchi, I.; Sogawa, Y.; Jinushi, M.; Aoki, Y.; Kitade, M.; Takeda, S. Single-incision laparoscopic surgery using an articulating monopolar for juvenile cystic adenomyoma. Minim. Invasive Ther. Allied Technol. 2013, 22, 312-315. [CrossRef] [PubMed]

27. Pontrelli, G.; Bounous, V.-E.; Scarperi, S.; Minelli., L.; Di, S.-S.-A.; Florio, P. Rare case of giant cystic adenomyoma mimicking a uterine malformation, diagnosed and treated by hysteroscopy. J. Obstet. Gynaecol. Res. 2015, 41, 1300-1304. [CrossRef]

28. Dadhwal, V.; Sharma, A.; Khoiwal, K. Juvenile Cystic Adenomyoma Mimicking a Uterine Anomaly: A Report of Two Cases. Eurasian J. Med. 2017, 49, 59-61. [CrossRef] [PubMed]

29. Peters, A.; Rindos, N.-B.; Guido, R.-S.; Donnellan, N.-M. Uterine-sparing Laparoscopic Resection of Accessory Cavitated Uterine Masses. J. Minim. Invasive Gynecol. 2018, 25, 24-25. [CrossRef]

30. Protopapas, A.; Kypriotis, K.; Chatzipapas, I.; Kathopoulis, N.; Sotiropoulou, M.; Michala, L. Juvenile Cystic Adenomyoma vs Blind Uterine Horn: Challenges in the Diagnosis and Surgical Management. J. Pediatric Adolesc. Gynecol. 2020, 33, 735-738. [CrossRef]

31. Wilcox, A.; Schmidt, M.; Luciano, D. Identification of Juvenile Cystic Adenomyoma Using High-Resolution Imaging. Obstet. Gynecol. 2020, 136, 1021-1024. [CrossRef] [PubMed] 